\title{
TAJEMNICA MIŁOSIERDZIA BOŻEGO W UJĘCIU ŚW. ZYGMUNTA SZCZĘSNEGO FELIŃSKIEGO
}

Prawda o miłosierdziu Bożym jest szeroko obecna we współczesnym nauczaniu Magisterium Kościoła. Warto jednak pamiętać, że była ona wyznawana i rozważana także w teologii wcześniejszych wieków. W tym artykule chcę ukazać teologiczne spojrzenie na tajemnicę miłosierdzia Bożego znanego polskiego teologa XIX wieku, arcybiskupa Warszawy Zygmunta Szczęsnego Felińskiego.

\section{PISMO ŚWIĘTE JAKO KSIĘGA BOŻEGO MILOSIERDZIA}

Prawda o miłosierdziu Bożym odsłania się w licznych tekstach Pisma Świętego. Pan miłosierny obdarza stworzonych przez siebie ludzi stanem łaski, wspierając ich po upadku1. Przypowieści o pasterzu poszukującym zagubionej owcy czy o synu marnotrawnym ukazują, jak bardzo upragnionym dla Ojca Niebieskiego jest powrót grzesznika. Miłosierdzie naszego Odkupiciela odsłania się w Jego postawie wobec jawnogrzesznicy (J 8,11). Pan uczy nas prośby o miłosierdzie Niebieskiego Ojca w codziennej modlitwie Ojcze nasz (Mt 6,12). Przestrzega przed potępieniem grzesznika w rozmowie z Piotrem skarżącym się na swojego brata (Mt 18, 22), czy w ostrych słowach skierowanych do Jakuba i Jana (Łk 9, 55). Uczy wprost i jednoznacznie:...odpuszczajcie a będzie wam odpuszczone...(Łk 6,37). Prawdę o miłosierdziu Bożym dostrzegamy w historii nawrócenia wielkich

\footnotetext{
${ }^{1}$ Por. Z. Sz. F e li ń s k i, Konferencje o powołaniu, Poznań 2001, s. 171.
} 
grzeszników: Szawła i Marii Magdaleny. Prawdę tę głosi św. Paweł (1 Kor 12,4.7) i św. Jakub (Jk 2,13). Dzieje Apostolskie, opisując męczeństwo św. Szczepana, wskazują, jak dzięki łasce Bożej, staje się możliwa miłość nieprzyjaciół².

Zygmunt Szczęsny Feliński, modląc się, korzystał z książeczki do nabożeństwa Złoty ołtarzyk. Znajdujemy w niej piękną litanię o miłosierdziu Bożym opartą na szeregu tekstów Starego i Nowego Testamentu ${ }^{3}$.

Rozważając Boże Objawienie, Feliński dostrzega wewnętrzny związek Bożych przymiotów. W opiekuńczym działaniu Opatrzności widzi szczególnie jasno mądrość i miłosierdzie Niebieskiego Ojca ${ }^{4}$.

\section{JEZUS CHRYSTUS JAKO PELNIA OBJAWIENIA BOŻEGO MILOSIERDZIA}

Feliński podkreśla bezmiar miłosierdzia, jakie Bóg okazuje człowiekowi upadłemu, by pozyskać serce, które pozostało obojętne wobec szczodrobliwości. Po grzechu pierworodnym Bóg w swoim miłosierdziu obiecał rodzajowi ludzkiemu przyjście Odkupiciela. Ta obietnica jest przekazywana nie tylko w Piśmie Świętym, ale i we wszystkich starożytnych religiach ${ }^{5}$.

Tajemnice wiary nie muszą człowieka trwożyć czy zniechęcać, mogą stać się bowiem niewyczerpanym źródłem światła i siły. Szczególnie tajemnica Odkupienia, ta zdumiewająca ofiara Boga dla człowieka, budzi zachwyt i uwielbienie, pozwala zapomnieć o sobie, a żyć tylko dla Boga ${ }^{6}$.

2 Por. Tenże, Wiara i niewiara w stosunku do szczęścia osobistego, Lwów 1886, s. 191-196.

3 Por. Złoty ołtarzyk czyli krótkie zebranie różnego nabożeństwa, Lipsk 1844, s. $159-166$.

${ }^{4}$ Por. Z. Sz. F e li ń s k i, Wiara i niewiara..., dz. cyt., s. 256.

5 Tamże, s. 248, 251.

${ }^{6}$ Por. Z. Sz. F e li ń s k i, Wiedza chrześcijańska i bezbożna wobec zadań społecznych, Lwów 1903, s. 340-341. 
Dzięki pomocy nadprzyrodzonej, której Pan udziela nam w swoim miłosierdziu, możemy poznawać Boga, człowieka i ich wzajemny związek w świetle wiary ${ }^{7}$. Przyjście Chrystusa na świat, przyniesienie przez Wcielone Słowo pełni Bożego objawienia, jest wielkim darem miłosierdzia Pana, który prowadzi człowieka ku prawdzie: $A \dot{z}$ wreszcie miłosierdzie Pańskie rozdarto tajemnicza zasłonę, co pod symbolicznymi znakami ukrywała coraz to bliższa rzeczywistość, $i$ Wcielone Stowo oznajmiło zdumionemu światu nieomylna prawde, już nie $w$ figurach, lecz w calym blasku swego majestatu ${ }^{8}$.

Feliński ukazuje wcielenie Syna Bożego, Jego ofiarę krzyżową i oddawanie się człowiekowi na pokarm w Eucharystii jako wyraz niepojętej miłości Boga do człowieka, miłości ofiarnej, gotowej do wyniszczenia siebie. Ta miłość do nas, niedoskonałych i skalanych grzechem, wzywa do ofiarnej odpowiedzi ${ }^{9}$.

Arcybiskup przypomina o życiodajnych zdrojach łaski, jakie wytryskują z przebitego boku Jezusa i łączą nasze serca z Jego Przenajświętszym Sercem. Zachęca byśmy korzystali z tego zdroju łaski przede wszystkim poprzez częstą komunię świętą łączącą się z dbałością o czystość sumienia ${ }^{10}$. W liście z zesłania dziękuje serdecznie za nadesłane przez siostry karmelitanki ozdobne przykrycie puszki z wizerunkiem Serca Jezusowego. Traktuje je jako zachętę do przeżywania cierpienia w duchu Chrystusowym, a więc w duchu poświęcenia za prześladowców ${ }^{11}$.

W perspektywie teologicznej Felińskiego chrześcijaństwo to religia miłosierdzia. Istnieje zasadnicza różnica między racjonalizmem, który nie przynosi żadnej ulgi przeżywającemu różne utrapienia

7 Por. Tenże, Wiara i niewiara..., dz. cyt., s. 133.

8 Tenże, Wiedza chrześcijańska..., z. cyt., s. 201.

9 Por. Tenże, Wiara i niewiara..., dz. cyt., s. 178-179.

10 Por. Miesiąc maj z arcybiskupem Felińskim, Warszawa 2001, s. 137.

11 Por. Z. Sz. F e l i ń s k i, List do siostry Marii Ksawery od Jezusa, karmelitanki, w'świecie Marii z Grocholskich, Czartoryskiej, 26 października/8 listopada 1874, Jarosław, Archiwum Główne Zgromadzenia Sióstr Franciszkanek Rodziny Maryi, Warszawa, F-c-7 nr 3, Pisma $n r 191$. 
człowiekowi a chrześcijaństwem, które pozwala dostrzec światłem wiary mądrość i miłosierdzie Stwórcy ${ }^{12}$.

\section{MILOSIERDZIE BOŻE W POSLANNICTWIE KOŚCIOLA}

W posłannictwie Kościoła Feliński wyróżnia, ściśle związane ze sobą, trzy elementy: ofiarę, modlitwę i miłosierdzie wobec duszy i ciała. Ten ostatni obejmuje szafarstwo słowa Bożego i sakramentów oraz różnego rodzaju posługi wobec potrzebujących. Szczególnie jest on obecny w życiu zgromadzeń zakonnych czynnych i apostolskich ${ }^{13}$.

Ustanowione przez Chrystusa sakramenty umożliwiają dostęp do skarbnicy łaski. Są lekarstwami, jakich potrzebuje człowiek podczas swojej doczesnej pielgrzymki. Nie ma ani jednej wewnętrznej potrzeby, której nie można by zaspokoić za pomocą sakramentów. Chrystus Pan pozostawił Kościołowi swoją Boską naukę, dzięki której człowiek może poznać Boga i Jego świętą wolę, by zmierzać do wiekuistego z Nim zjednoczenia $\mathrm{w}$ niebie. Zbawiciel przyniósł nam z nieba jeszcze jeden skarb: święty ogień miłości Boga i bliźniego. Miłość nadprzyrodzona rodzi w sercu człowieka pragnienie zjednoczenia z Bogiem i chęć pomocy bliźniemu w podobnym zjednoczeniu ${ }^{14}$. Feliński widzi nieograniczone miłosierdzie Stwórcy w rozdzielaniu darów i posług między ludzi w Kościele. Duch miłości sprawia, że z radością spełniane są nawet najbardziej pospolite posługi potrzebne Chrystusowemu Ciału ${ }^{15}$.

Kościół umacnia nas sakramentami, karmi mlekiem chrześcijańskiej nauki, składa do poświęconej ziemi nasze martwe ciało. Następnie zanosi za zmarłego modlitwy i ofiarę Krwi Zbawiciela, chociaż fale zapomnienia dawno już pochłonęły pamięć o nim.

\footnotetext{
12 Por. Tenże, Wiara i niewiara..., dz. cyt., s. 274.

13 Por. Tenże, Listy ascetyczne pisane z Jarosławia nad Wołgą do Sióstr Rodziny Maryi w Warszawie, Warszawa 1995, s. 197-198.

${ }_{14}$ Por. Tenże, Wiara i niewiara..., dz. cyt., s. 275-277, 281-283.

15 Por. Tenże, Konferencje duchowne, Poznań 2002, s. 48-49.
} 
Kościół wspiera nas także w doczesnych potrzebach, broniąc wartości moralnych, chroniąc światło nauki, przypominając możnym o ich obowiązkach, pocieszając w strapieniu i wspomagając w nędzy ${ }^{16}$.

Przeciwnicy Kościoła zarzucają mu, że jest tylko biernym świadkiem ludzkiego cierpienia, zachęcającym strapionych do rezygnacji, bezczynnym wobec niesprawiedliwości społecznej, obojętnym wobec cierpień i niedoli doczesnych. W rzeczywistości Kościół troszczy się zarówno o ludzkiego ducha, jak i ciało inspirowany Ewangelią, która cała oddycha miłością.

To w Kościele powstawały w ciągu wieków różnego rodzaju instytucje odpowiadające na ludzkie potrzeby: szkoły, szpitale, przytułki dla starców, ułomnych czy obłąkanych, domy dla porzuconych dzieci, zakłady dla pragnących naprawić swoje życie, inicjatywy wykupu jeńców. Te dobroczynne instytucje zostały w dużej mierze przejęte przez państwo. Jednak w zakładach państwowych wysokie są koszty administracji, duże wydatki na cele reprezentacyjne, a ponadto często zdarzają się nadużycia. Pomoc przekazywana jest nie najbardziej potrzebującym, ale najgłośniej domagającym się wsparcia albo posiadającym znaczących protektorów. Urzędnicy dążą do własnej kariery. W zgromadzeniach, towarzystwach czy bractwach organizowanych przez Kościół dominuje duch służby bliźnim z miłości do Boga. Wyraża się on w gotowości poświęcenia potrzebującym swojej osoby i mienia. Ogień Bożej miłości sprawia, że powoli zabliźniają się rany duszy, biedacy przestają narzekać, rodzi się nadzieja, widoczny jest pokój, zgoda i radość nawet wśród ubóstwa. Autor dostrzega, że także w instytucjach kościelnych zdarzają się niekiedy nadużycia, ale są one zwalczane m.in. przez reformowanie istniejących zgromadzeń zakonnych i tworzenie nowych ${ }^{17}$. J. Salij zwraca uwagę, że nie zawsze działalność charytatywna pokrywa się z czynieniem miłosierdzia. Może towarzyszyć jej brak szacunku dla osoby, której

\footnotetext{
${ }^{16}$ Por. Tenże, Wiara i niewiara..., dz. cyt., s. 287-290.

17 Tamże, s. 94-109.
} 
staramy się pomóc, postawa wyższości, dążenie do zdobycia popularności i poparcia ${ }^{18}$.

Ucząc o miłosierdziu Bożym odsłaniającym się w posłudze Kościoła, Feliński potwierdza swoje słowa działaniem. Jako młody kapłan rozwija szeroką działalność charytatywną w Petersburgu. Swoje środki i czas hojnie przeznacza m.in. na schronisko prowadzone przez siostry Rodziny Maryi. Ten katolicki zakład dobroczynny, wspierający sieroty, osoby starsze i bezdomne, został założony przez Felińskiego w roku 1857. Jako arcybiskup Warszawy troszczy się o rozwój instytucji chrześcijańskiego miłosierdzia i inicjuje powstawanie nowych zajmujących się np. opuszczonymi dziećmi czy zagrożonymi moralnie dziewczętami. Na zesłaniu w Jarosławiu wspiera materialnie i duchowo polskich zesłańców i ubogich mieszkańców ${ }^{19}$. W Galicji opiekuje się schorowanymi kapłanami powracającymi z zesłania, osobiście ich pielęgnując.

Feliński stara się także ukazać piękno czynów miłosierdzia polskich kobiet XIX wieku. Przypomina m.in. postać Ksawery Grocholskiej zaangażowanej w działalność Komitetu Opieki nad Zesłańcami, który wspierał Sybiraków nie tylko pieniędzmi czy odzieżą, ale także dbał o ich sferę duchową poprzez modlitwę, korespondencję, pomoc w nawiązywaniu kontaktu z rodzinami, wysyłanie książek, przekazywanie wiadomości, czy niesienie otuchy ${ }^{20}$.

\section{MARYJA MATKA MILOSIERDZIA}

Feliński ukazuje Maryję jako Matkę miłosierdzia wspierającą polskich zesłańców, którzy na obczyźnie bez kapłana i wsparcia wspólnoty wiernych, w głodzie i zimnie starali się wytrwać w wierze

18 Por. J. S a li j, Szczególna potęga miłości, w: Świetlisty szlak. Karol Wojtyła Jana Paweł II o miłosierdziu, Warszawa 2010, s. 160-161.

19 Por. T. A. Fr ą c e k, Zesłaniec nad brzegami Wotgi. Miniatury z życia abp. Zygmunta Szczęsnego Felińskiego, Wrocław 2013, s. 181, 258-259, 343-346.

${ }^{20}$ Por. Z. Sz. F e li ń s k i, Pamiętniki Xawery z Brzozowskich Grocholskiej, uporzadkowane $i$ dopetnione na podstawie własnych jej listów $i$ wspótczesnych korespondencyj, Kraków 1894, s. 283-303. 
katolickiej, Maryję, która przy śmierci otwiera cierpiącym bramy nieba ${ }^{21}$. O Maryi Matce Miłosierdzia wielokrotnie wypowiada się Jan Paweł II. Wskazuje, że możemy Jej przyzywać jako Mater Misericordiae, ponieważ jest Matką Jezusa, w którym Bóg objawił swoją miłość i ponieważ u stóp krzyża, zespolona z tajemnicą paschalną swojego Syna, stała się Matką uczniów Chrystusa, Matką Kościoła i całej ludzkości 22 .

\section{MILOSIERDZIE BOŻE WOBEC GRZESZNIKA}

Autor podkreśla nieskończoność miłosierdzia Bożego, którego doświadczamy w sakramencie pokuty poprzez obmycie win i odpuszczenie wiecznych kar. Pozostaje jednak potrzeba pokuty za własne grzechy, jak i grzechy innych członków Kościoła, w którym stanowimy jedno Ciało ${ }^{23}$.

Częste korzystanie z sakramentu pokuty a szczególnie niezwłoczne korzystanie po popełnieniu grzechu śmiertelnego jest sięgnięciem do daru Bożego miłosierdzia, które ratuje człowieka z zatracenia. Feliński zachęca przy tym, by nie traktować sakramentu pokuty jedynie jako trybunału, ale także jako okazję spotkania z lekarzem, który uzdrawia niemoce duszy i z przewodnikiem, duchowym ojcem, który wskazuje kierunek, zachęca i pociesza w utrapieniach ${ }^{24}$.

Najbardziej zatwardziały grzesznik, dopóki żyje na ziemi, może się opamiętać. Gdy odwróci swoje serce od zła i skłoni wolę ku dobremu, może naprawić najgorszą nawet przeszłość. Tutaj widoczne jest wielkie i niewyczerpane miłosierdzie Pana. Feliński wyraźnie odróżnia grzech i grzesznika. Grzech winniśmy nienawidzić, zło

${ }^{21}$ Por. Miesiąc maj z arcybiskupem Felińskim, dz. cyt., s. 157-162.

22 Por. J a n P aw e ł II, Matka Miłosierdzia. Rozważanie przed modlitwa Regina coeli, Rzym 22 kwietnia 2001, w: Jan Pawet II o Bożym Miłosierdziu i św. Faustynie, P. S z w e d a (opr.), Kraków 2008, s. 65-66.

${ }^{23}$ Por. Z. Sz. F e l i ń s k i, Listy ascetyczne pisane z Jarosławia nad Wotga do Sióstr Rodziny Maryi w Warszawie, Warszawa 1995, s. 93.

${ }^{24}$ Por. Tenże, Konferencje duchowe, dz. cyt., s. 394-395. 
złem wyraźnie nazwać. Grzesznika zaś szczerze ukochać, wspierając go we wszystkich potrzebach duszy i ciała ${ }^{25}$.

W literackiej twórczości Felińskiego spotykamy przejmujące postacie nawracających się grzeszników. Zakonnik, wzywający do darowania życia zdrajcy i zabójcy księciu Rogerowi, odwołuje się do Bożego miłosierdzia, którego wszyscy potrzebujemy. Przypomina, że skruszony łotr może osiągnąć zbawienie, może stać się nawet jak Szaweł wybranym naczyniem Bożej łaski. Doświadczony mnich dostrzega wewnętrzną przemianą człowieka, dzięki której zbrodniarz staje się bratem ${ }^{26}$. Józef, umierający samobójca, dziękuje miłosierdziu Bożemu, że przed śmiercią dostrzegł swoje błędy, wyspowiadał się ze skruchą, przyjął wiatyk i docenił skarby, jakie Chrystus wysłużył swoją męką ${ }^{27}$.

Feliński dostrzega działanie nieskończonego miłosierdzia Bożego w swoim życiu, szczególnie w odniesieniu do oczyszczenia motywów, które skłoniły go do wybrania stanu duchownego. W jego ocenie początkowo dominowało poczucie zawodu związanego $\mathrm{z}$ nieudanym powstaniem i problemami osobistymi oraz pragnienie służby ojczyźnie. Pan Bóg nie odrzucił ofiary, chociaż przyniesionej z pychą i zarozumiałością ${ }^{28}$.

Także człowiek sprawiedliwy często upada i przeżywa wyrzuty sumienia. Jednak pamięć o miłosierdziu Bożym pozwala mu żyć nadzieją: pomny wszakże na nieskończone miłosierdzie Pańskie, co wśród nędzy naszej najwięcej obfituje, nie upada na duchu, bo wie, że byle korzyt się i ufat, Ojciec Niebieski wesprze go, gdy się zachwieje, podźwignie, gdy się obali, umocni, gdy powstanie ${ }^{29}$.

W listach do sióstr zakonnych Feliński zachęca do pokory i ukazuje jej związek z uznaniem prawdy o miłosierdziu Bożym. Wszelkie

\footnotetext{
25 Por. Tenże, Wiara i niewiara..., dz. cyt., s. 192-193.

${ }_{26}$ Por. Tenże, Prakseda. Oskar $i$ Wanda. Dwa poematy z teki Anhellego, Szczecinek 2010, s. 92-93.

27 Por. Tenże, Wiara i niewiara..., dz. cyt., s. X-XIV.

${ }_{28}$ Por. Tenże, Pamiętniki, Warszawa 2009, s. 379-380.

29 Tenże, Wiara i niewiara..., dz. cyt., s. 50.
} 
dobro, jakie w nas jest i może być, pochodzi od Boga. On nie tylko udziela nam darów swej szczodrobliwości, ale i przebacza, gdy ich niewdzięcznie nadużywamy. Tymczasem my posiadane przymioty próbujemy przypisywać tylko własnej zasłudze ${ }^{30}$.

\section{MILOSIERDZIE BOŻE W DZIEJACH NARODU}

Na zesłaniu Feliński boleśnie przeżywa nieszczęścia narodu, ma przed oczami spustoszone świątynie, zniszczone przydrożne krzyże, odebrane klasztory, zakazy obejmowania przez Polaków urzędów, pracy nauczyciela, służby na kolei, kupowania ziemi, opieki nad sierotami. Prosząc o wolność dla ojczyzny, o ochronę przed okrucieństwem zaborców przyzywa Bożego miłosierdzia ${ }^{31}$.

Feliński dostrzega przejaw miłosierdzia Bożego w cierpliwym oczekiwaniu Boga na nawrócenie narodu, na wypełnienie ślubów Jana Kazimierza zarówno w odniesieniu do życia religijnego, jak i sprawiedliwości społecznej32.

Dzięki miłosierdziu Bożemu w okresie niewoli w pewnej mierze dokonał się proces odrodzenia narodu. Powstało kilka nowych zgromadzeń zakonnych. Zwiększyła się liczba powołań wśród wyższych warstw społecznych. Zdecydowanie zmniejszyła się liczba rozwodów, młodzi Polacy częściej brali udział w rekolekcjach i zapisywali się do katolickich stowarzyszeń. Osoby uczestniczące we Mszy św. i komunii oraz postach nie spotykały się już z pogardą i szyderstwem. Lenistwo, marnotrawstwo, hazard i rozpusta zaczęły być potępiane przez opinię publiczną ${ }^{33}$.

30 Por. Tenże, Listy ascetyczne..., dz. cyt., s. 42-46.

${ }^{31}$ Por. Tenże, Tęcza [wiersz], Archiwum Główne Zgromadzenia Sióstr Franciszkanek Rodziny Maryi, Warszawa, Pisma nr 807.

$32 . . . k a r a$ zaś za to wiarołomstwo długo przez miłosierdzie Boże wstrzymywana, zaciażyła wreszcie na trzecim i czwartym pokoleniu. Por. Miesiac maj z arcybiskupem Felińskim, dz. cyt., s. 174.

33 Por. Z. Sz. Fe l i ń s k i, Pod wodza Opatrzności, Warszawa 2010, s. 38, 64-67. 


\section{ZNACZENIE POSTAWY \\ UFNOŚCI W MILOSIERDZIE BOŻE PODCZAS DOŚWIADCZEŃ}

Feliński zachęca do ufności w miłosierdzie Boże szczególnie podczas utrapień i trudności. Doświadczają ich często bliscy mu członkowie rodziny. Zachęca również do spojrzenia na trudności jako na czas próby. Wskazuje na Bożą opiekę nad rodziną wyrażającą się we wzajemnej solidarności, gotowości dzielenia się z drugim. Zaufanie Panu Bogu pozwala znaleźć pociechę i osiągnąć spokój także w sytuacji materialnych niepowodzeń. Serce mi się ściska na widok tylu utrapień, jakie dotykaja nas zewsząd, a jednak przez tzy jakaś żywa nadzieja świeci, że to tylko próba, że wszystko ku lepszemu się skłoni, skoro ja przetrwamy z ufnościa w miłosierdzie Boże i z poddaniem się, jakiego On od nas wymaga ${ }^{34}$.

Feliński pamięta, że podczas ciężkiej choroby jego siostry Pauliny cała rodzina a szczególnie babcia przyzywała miłosierdzia Pańskiego poprzez nowenny, nabożeństwa, posty, jałmużny a także pielgrzymkę ${ }^{35}$.

W odpowiedzi na list Felińskiego i innych polskich biskupów, nadesłany z okazji kanonizacji męczenników japońskich (8 czerwca 1862), papież Pius IX wyraził przekonanie, że polscy biskupi nie przestaną odważnie bronić wolności Kościoła i prosić obfitego w miłosierdzie Boga o pomoc prześladowanym i nawrócenie prześladowców ${ }^{36}$.

Wobec wypędzenia z Poznania w roku 1874 przez rząd pruski sióstr karmelitanek bosych Feliński wskazuje na dopuszczenie przez Miłosiernego Pana tego trudnego doświadczenia, które służy świętości sióstr a przez to przemianie całego świata. Zachęca siostry, by

34 Tenże, List do matki, 16 stycznia 1854, Petersburg; w: Z. Sz. F e l iń s k i, Listy Świętego do Matki Ewy z Wendorffów Felińskiej z lat 1838-1860, Warszawa 2012, s. 316-317.

35 Tenże, Paulina córka Ewy Felińskiej, Warszawa 1996, s. 59-60.

36 Por. S. P r a w d z i c k i [I. P o 1 k o w s k i], Wspomnienie o Zygmuncie Szczęsnym Felińskim Arcybiskupie Metropolicie Warszawskim, Kraków 1866, s. 142. 
w tym wydarzeniu dostrzegły poniżenie Syna Bożego, któremu mogą towarzyszyć jak Maryja pod krzyżem ${ }^{37}$.

W liście do biskupa Wincentego Popiela Feliński zapewnia o swojej modlitwie za przyjaciela, życząc mu w rozpoczynającym się roku Bożego błogosławieństwa, obfitości Bożych darów i łask. Ufa, że gorliwość biskupa wyda owoce, bo ten, który pokłada nadzieję w Panu doświadczy Jego miłosierdzia ${ }^{38}$.

Szczególne znaczenie ma ufność w Boże miłosierdzie u kresu ludzkiego życia. Feliński opisuje śmierć kapucyna o. Agrypina (Piotra Pawła Konarskiego), który po wybuchu powstania styczniowego działał jako kapelan powstańców walczących z rosyjskim zaborcą. Skazany na śmierć, 12 czerwca 1863 roku został stracony na stokach cytadeli. Przed powieszeniem, pełen ufności Bożemu miłosierdziu, dziękował, że może ofiarować Bogu swoje życie. Prosił usilnie o odprawienie Mszy Świętej za swoją grzeszną duszę $e^{39}$. Zaufanie Bożemu miłosierdziu łączy się tutaj ze świadomością własnej grzeszności i koniecznością modlitwy za zmarłych.

\section{UMIEJĘTNOŚĆ DOSTRZEŻENIA BOŻEGO MILOSIERDZIA}

Po aresztowaniu i skazaniu na zesłanie matki, rodzina Felińskich znalazła się w trudnym położeniu. Tym niemniej dzieciom nie brakuje chleba, mogą też nadal zdobywać wiedzę. Paulina Felińska dostrzega tutaj działanie Boga, który natchnął miłosierdziem ludzkie serca i sprawił, że nauczyciele pracują bez wynagrodzenia, a jeden z nich ofiarowuje nawet potrzebującym swoje niewielkie oszczędności ${ }^{40}$.

37 Por. Tenże, List do przełożonej klasztoru karmelitanek w Poznaniu, 26 października/8 listopada 1874, Jarosław, Archiwum Główne Zgromadzenia Sióstr Franciszkanek Rodziny Maryi, Warszawa, F-c-7 nr 2, Pisma nr 190.

38 Por. Tenże, List do biskupa Wincentego Popiela, 22 grudnia 1875/3 stycznia 1876; Archiwum Główne Zgromadzenia Sióstr Franciszkanek Rodziny Maryi, Warszawa, F-c-10, nr 37.

39 Por. Tenże, Pamiętniki, Warszawa 2009, s. 583-584.

40 Por. Tenże, Paulina córka Ewy Felińskiej, dz. cyt., s. 100-101. 
Feliński zachęca do postawy głębokiej wdzięczności za wszelkie dary, jakie otrzymujemy od Boga. Tylko wtedy, gdy nie przyznajemy sobie prawa do żadnych darów ani nie przywłaszczamy ich sobie, możemy stać się narzędziami Bożego miłosierdzia ${ }^{41}$.

Feliński zauważa, że odrodzony przez łaskę artysta przestaje traktować sztukę jako narzędzie służące własnej chwale, przestaje też poddawać się wymaganiom ducha czasu, ale zraniony grotem Bożej miłości, stara się pokazać dzieła dobroci i miłosierdzia Boga od stworzenia aż do dnia dzisiejszego, a szczególnie niepojętą miłość Zbawiciela wobec nas, ludzi ${ }^{42}$. Wezwanie do głoszenia miłosierdzia Bożego nie jest czymś zewnętrznym, ale wypływa z doświadczenia człowieka, który spotyka Boga.

\section{ZYGMUNT SZCZĘSNY FELIŃSKI A SIOSTRA FAUSTYNA}

Zgromadzenie Sióstr Matki Bożej Miłosierdzia powstało 1 listopada 1862 roku w Warszawie. Wtedy to matka Teresa Potocka otworzyła przy ulicy Żytniej pierwszy dom miłosierdzia. W tym dniu abp Zygmunt Feliński poświęcił ich dzieło opieki nad dziewczętami potrzebującymi specjalnej troski, a wcześniej zakupił dla nich posesję z dworkiem, gdzie siostry, popularnie nazywane magdalenkami, starały się pomóc prostytutkom pragnącym zmienić swoje życie, kobietom skazanym na kary więzienia, a także niepełnoletnim dziewczętom ze środowisk zagrożonych patologią. W domu przy ulicy Żytniej 3/9 zapuka do furty klasztornej i wstąpi do zgromadzenia siostra Faustyna Kowalska apostołka Bożego miłosierdzia. Tutaj będzie pomagała w kuchni, przeżywała kryzysy, ale także doświadczy objawienia się Jezusa Chrystusa ${ }^{43}$. Bp Feliński nie tylko sprowadził

${ }^{41}$ Por. Tenże, Konferencje o powołaniu, dz. cyt., s. 123.

${ }^{42}$ Por. Tenże, Wiedza chrześcijańska..., dz. cyt., s. 342-343.

${ }^{43}$ Por. T. A. Fr ą c e k, Zesłaniec nad brzegami Wołgi. Miniatury z życia abp. Zygmunta Szczęsnego Felińskiego, Wrocław 2013, s. 259. Por. E. C z a c z k o w s k a, Siostra Faustyna. Biografia świętej, Kraków 2012, s. 71-84. 
do Warszawy, ale też wsparł inicjatywę powstania i rozwoju zgromadzenia zakonnego przyszłej świętej.

Jan Paweł II, podczas swojej ostatniej pielgrzymki do ojczyzny, konsekrował świątynię w Łagiewnikach i zawierzył cały świat Bożemu miłosierdziu, a następnego dnia, 18 sierpnia 2002 roku podczas Mszy św. na Błoniach Krakowskich, beatyfikował kilku świadków miłosierdzia: arcybiskupa Zygmunta Szczęsnego Felińskiego, księdza Jana Wojciecha Balickiego, ojca Jana Beyzyma i siostrę Sancję Janinę Szymkowiak. Podczas wygłoszonej wtedy homilii zwrócił uwagę na oddanie Felińskiego sprawie miłosierdzia wyrażające się m.in. założeniem w 1857 roku Zgromadzenia Sióstr Franciszkanek Rodziny Maryi, ale także w obronie wolności narodowej ${ }^{44}$.

Siostra Faustyna ujmuje miłosierdzie jako przymiot Boga, który jest pełen miłości, dobroci i litości. Miłosierdzie Boga jest niezgłębione, nieskończone, niepojęte, niewyczerpane, niezbadane, niewypowiedziane i niezmierzone ${ }^{45}$. Takie ujęcie, opierające się na objawieniu biblijnym, bliskie jest także Felińskiemu.

\section{NIEBEZPIECZEŃSTWO MANIPULACJI PRAWDĄ O BOŻYM MILOSIERDZIU}

W odpowiedzi na interwencję Felińskiego w obronie prześladowanych, w swoim liście książę Gorczakow podkreśla, że władze rosyjskie muszą być stanowcze wobec buntujących się Polaków a przypadki zbytniej surowości, które być może miały miejsce, wynikały z ludzkiej ułomności, wobec której biskup Warszawy nie może odmówić płaszcza chrześcijańskiego miłosierdzia. List kanclerza Feliński przyjął z oburzeniem. Cytadela warszawska pełna jest więźniów trzymanych na słomie ruszającej się od robactwa. Polacy

${ }^{44}$ Por. Bóg bogaty w miłosierdzie. Ostatnia pielgrzymka Ojca Świętego Jana Pawła II do Ojczyzny 16-19 sierpnia 2002. Przemówienia i homilie, Warszawa 2006, s. 54-61.

${ }^{45}$ Por. M. B e r n y ś, Miłosierdzie największy przymiot Boga u świętej Faustyny $i w$ dziejach Kościoła, Ząbki 2016, 66-67. 
aresztowani są za noszenie żałoby, konfederatki czy białego orzełka w pierścionku. Nie ma litości dla kobiet i dzieci. Jedna z dziewcząt, śpiewających w kościele zakazane pieśni, po aresztowaniu przez policję, wskutek poniżającego traktowania, straciła życie. Tymczasem kanclerz domaga się pobłażania dla oprawców panoszących się na cudzej ziemi, których okrucieństwo przekracza nawet granice prawa państwa rosyjskiego ${ }^{46}$.

\section{MOŻLIWOŚĆ ODRZUCENIA BOŻEGO MILOSIERDZIA}

Feliński krytycznie ocenia teorie filozoficzne, które przeczą możliwości nadprzyrodzonego stosunku człowieka z Bogiem. Widzi tutaj niebezpieczeństwo racjonalizmu odrzucającego najwspanialsze dary Boże tylko dlatego, że przekraczają one możliwości poznawcze ludzkiego rozumu. W ten sposób odrzucany jest najcenniejszy dar miłosierdzia Stwórcy, jakim jest doskonałe i wieczne szczęście ${ }^{47}$.

Odrzucenie Boga prowadzi do bezwzględności w życiu społecznym, nieludzkiego traktowania nieletnich robotników w fabrykach, mogąc doprowadzić nawet do zabijania dzieci chorych, ułomnych czy upośledzonych ${ }^{48}$.

Biskup wskazuje, że zatwardziały grzesznik niejednokrotnie nawet $\mathrm{w}$ ostatniej godzinie swojego życia odrzuca Boże miłosierdzie, bluźni ustami i sercem i z nienawiścią odnosi się do religii, miota się nawet na wspomnienie o sakramentach świętych. Widoczny jest tutaj niepokój duszy, w której po raz ostatni odzywa się naglące wezwanie łaski. Dusza jednak może pozostać skrępowana pychą i zarażona niewiarą. Istnieje możliwość potępienia w stosunku do tych, którzy nie zechcą zwrócić się ku miłosierdziu Pana ${ }^{49}$.

\footnotetext{
46 Por. Z. Sz. Fe 1 i ń s k i, Pamiętniki, dz. cyt., s. 498-501, 514-515.

${ }^{47}$ Por. Tenże, Wiara i niewiara..., dz. cyt., s. 37-39.

${ }^{48}$ Por. Tenże, Wiara i niewiara w stosunku do szczęścia społecznego, Kraków 1890, s. 46-47.

${ }^{49}$ Por. Tenże, Wiara i niewiara..., dz. cyt., s. 52-53, 267.
} 


\section{PODSUMOWANIE}

Arcybiskup Warszawy Zygmunt Szczęsny Feliński wielokrotnie podejmował problematykę miłosierdzia Bożego. Wskazywał na liczne teksty Pisma Świętego, w którym odsłania się prawda o tym Bożym przymiocie. W tajemnicy Wcielenia i Odkupienia można dostrzec wielki dar miłosierdzia Pana, który staje się dla człowieka niewyczerpanym źródłem światła i siły. Miłosierdzie Boże odsłania się w posłannictwie Kościoła przede wszystkim w darze sakramentów i Boskiej nauki, ale także w wielowiekowej, kreatywnej, pełnej poświęcenia działalności odpowiadającej na różnorodne potrzeby człowieka. Szczególnie uprzywilejowane miejsce działania miłosierdzia Bożego stanowi sakrament pokuty będący ratunkiem dla grzesznika i okazją spotkania z lekarzem i duchowym przewodnikiem. Feliński dostrzega działanie miłosierdzia Bożego w historii naszego narodu, przede wszystkim w procesie moralno-religijnego odrodzenia dokonującego się w trudnym czasie niewoli. Ufność Bożemu miłosierdziu nabiera szczególnego znaczenia podczas przeżywanych trudności i niepowodzeń, stanowiąc zachętę do wytrwałej modlitwy za siebie $\mathrm{i}$ innych oraz chroniąc przed rozpaczą i skupieniem na sobie i swoich problemach.

Istnieje pewien związek między apostołką Bożego Miłosierdzia siostrą Faustyną Kowalską a Zygmuntem Felińskim. Biskup sprowadził do Warszawy siostry Matki Bożej Miłosierdzia i ofiarował im dom. W tym miejscu będzie zdobywała formację zakonną przyszła święta. Zygmunt Feliński w niektórych wystąpieniach rosyjskiego zaborcy dostrzega niebezpieczeństwo manipulacji orędziem o Bożym miłosierdziu, próbę wykorzystania go do pomniejszania i usprawiedliwiania ludzkich zbrodni. Ostrzega, że człowiek niestety jest zdolny do odrzucenia wielkiego daru miłosierdzia Bożego w życiu doczesnym i wiecznym. 


\section{The mystery of the Divine Mercy according to Zygmunt Szczęsny Feliński \\ Summary}

The Archbishop of Warsaw Zygmunt Szczęsny Feliński wrote about the topic of the Divine Mercy many times. He referred to the numerous texts of the Holy Scripture which reveal the truth about this attribute of God. The great gift of God's mercy, which is man's inexhaustible source of light and strength, can be seen through the secret of the Incarnation and Redemption. The Divine Mercy is transmitted through the mission of the Church, in particular through the gift of the sacraments and God's teaching, but also through its activity spread through the centuries, which responded to the various needs of man with creativity and devotion. The sacrament of penance is a privileged place of receiving God's mercy. The sinner can meet the doctor and the spiritual guide. Feliński sees the impact of the Divine Mercy on the history of our nation, especially in the process of the moral and religious renewal in the difficult time of captivity. Trust in the Divine Mercy is of crucial importance during the times of hardships and failures. It encourages believers to pray faithfully for themselves and others. It protects against despair and over-focusing on oneself and one's problems.

A certain relationship between the apostle of the Divine Mercy, sister Faustyna Kowalska and Zygmunt Feliński can be observed. It was the Bishop who brought the sisters of Our Lady of Mercy to Warsaw and offered them a house there. It was in this place that the future saint received her formation. Zygmunt Feliński observes that some of the speeches of the Russian ruler present the danger of manipulating the message about the divine mercy, as they are an attempt to diminish and justify human crimes. He warns that unfortunately man is capable of rejecting the great gift of the divine mercy in earthly and eternal life.

Słowa kluczowe: miłosierdzie Boże, Feliński Zygmunt Szczęsny arcybiskup, siostra Faustyna Kowalska, miłosierdzie, niebezpieczeństwo manipulacji

Keywords: divine mercy, Feliński Zygmunt Szczęsny archbishop, sister Faustyna Kowalska, mercy, danger of manipulation

Nota 0 autorze: ks. Grzegorz Bachanek - dr hab. teologii dogmatycznej, adiunkt w Katedrze Mariologii na Wydziale Teologicznym Uniwersytetu Kardynała Stefana Wyszyńskiego w Warszawie; e-mail: g.bachanek@uksw.edu.pl 


\section{Bibliografia:}

Bernyś M., Miłosierdzie największy przymiot Boga u świętej Faustyny $i$ w dziejach Kościoła, Ząbki 2016.

Bóg bogaty w miłosierdzie. Ostatnia pielgrzymka Ojca Świętego Jana Pawła II do Ojczyzny 16-19 sierpnia 2002. Przemówienia i homilie, Warszawa 2006.

Czaczkowska E., Siostra Faustyna. Biografia świętej, Kraków 2012.

Feliński Z. Sz., Pamiętniki, Warszawa 2009.

Feliński Z. Sz., Konferencje duchowe, Poznań 2002.

Feliński Z. Sz., Konferencje o powołaniu, Poznań 2001.

Feliński Z. Sz., List do biskupa Wincentego Popiela, 22 grudnia 1875/3 stycznia 1876; Archiwum Główne Zgromadzenia Sióstr Franciszkanek Rodziny Maryi, Warszawa, F-c-10, nr 37.

Feliński Z. Sz., List do przełożonej klasztoru karmelitanek w Poznaniu, 26 października/8 listopada 1874, Jarosław, Archiwum Główne Zgromadzenia Sióstr Franciszkanek Rodziny Maryi, Warszawa, F-c-7 nr 2, Pisma nr 190.

Feliński Z. Sz., List do siostry Marii Ksawery od Jezusa, karmelitanki, w świecie Marii z Grocholskich, Czartoryskiej, 26 października/8 listopada 1874, Jarosław, Archiwum Główne Zgromadzenia Sióstr Franciszkanek Rodziny Maryi, Warszawa, F-c-7 nr 3, Pisma $n r 191$.

Feliński Z. Sz., Listy ascetyczne pisane z Jarosławia nad Wotga do Sióstr Rodziny Maryi w Warszawie, Warszawa 1995.

Feliński Z. Sz., Listy Świętego do Matki Ewy z Wendorffów Felińskiej z lat 18381860, Warszawa 2012.

Feliński Z. Sz., Pamiętniki Xawery z Brzozowskich Grocholskiej, uporządkowane i dopetnione na podstawie własnych jej listów $i$ wspótczesnych korespondencyj, Kraków 1894.

Feliński Z. Sz., Paulina córka Ewy Felińskiej, Warszawa 1996.

Feliński Z. Sz., Pod wodza Opatrzności, Warszawa 2010.

Feliński Z. Sz., Prakseda, Oskar i Wanda. Dwa poematy z teki Anhellego, Szczecinek 2010.

Feliński Z. Sz., Tęcza[wiersz], Archiwum Główne Zgromadzenia Sióstr Franciszkanek Rodziny Maryi, Warszawa, Pisma nr 807.

Feliński Z. Sz., Wiara i niewiara w stosunku do szczęścia osobistego, Lwów 1886.

Feliński Z. Sz., Wiara i niewiara w stosunku do szczęścia społecznego, Kraków 1890.

Feliński Z. Sz., Wiedza chrześcijańska i bezbożna wobec zadań społecznych, Lwów 1903. 
Frącek T. A., Zesłaniec nad brzegami Wołgi. Miniatury z życia abp. Zygmunta Szczęsnego Felińskiego, Wrocław 2013.

Jan Pawet II o Bożym Miłosierdziu i św. Faustynie, opr. P. Szweda, Kraków 2008. Miesiac maj z arcybiskupem Felińskim, Warszawa 2001.

Prawdzicki S. [I. Polkowski], Wspomnienie o Zygmuncie Szczęsnym Felińskim

Arcybiskupie Metropolicie Warszawskim, Kraków 1866.

Świetlisty szlak. Karol Wojtyła - Jana Paweł II o miłosierdziu, Warszawa 2010.

Złoty ołtarzyk, czyli krótkie zebranie różnego nabożeństwa, Lipsk 1844. 